\title{
PODSTAWOWE CECHY CZESKIEGO PRAWA WODNEGO Z POLSKIEJ PERSPEKTYWY
}

\section{BASIC FEATURES OF THE CZECH WATER LAW FROM THE POLISH POINT OF VIEW}

Artykuł recenzyjny:

Zdeněk Strnad, Veronika Vytejčkova, Zdeněk Horaček, Jaroslava Nietscheova, Michal Sobotka, Alena Klikova, Vodni pravo, Fakulta rybařstvi a ochrany vod, Jihočeska univerzita v Českych Budějovicich, 2013, s. 226.

* Prof. dr hab., Instytut Nauk Prawnych PAN.

** Dr hab., Instytut Nauk Prawnych PAN. 


\section{STRESZCZENIE}

Celem tego szkicu jest przedstawienie - na tle czeskiego monograficznego opracowania prawa wodnego - kilku podstawowych cech czeskiego prawa wodnego: historii prawa wodnego, jego źródeł, miejsca w systemie prawa, instrumentów prawnych, statusu prawnego wód, administracji wodnej oraz skonfrontowanie ich z odpowiednikami w polskim prawie wodnym.

\section{Słowa kluczowe}

Prawo wodne; ustawa wodna; zarządzanie wodami; administracja wodna.

\section{ABSTRACT}

The aim of this paper is to present - on the background of the Czech monographic study of water law - some basic features of the Czech water law: the history of water law, its sources, its place in the legal system, legal status of water, legal instruments, water administration, as well as to confront them with their equivalents in the Polish water law.

\section{Keywords}

Water law; water act; water management; water administration.

\section{UWAGI WSTĘPNE}

Wyraźny w ostatnich dwóch latach wzrost zainteresowania doktryny polskiej problematyką prawa wodnego ${ }^{1}$ skłania do przyjrzenia się jej także z perspektywy komparatystycznej.

1 M. Kałużny, Prawo wodne. Komentarz, Warszawa 2012; J. Rotko, Ramowa dyrektywa wodna - analiza prawna, Poznań 2013; B. Rakoczy (red.), Z. Bukowski, K. Szuma, Prawo wodne. Komentarz, Warszawa 2013; B. Rakoczy (red.), Wybrane problemy prawa wodnego, Warszawa 2013. 
Dobrą okazję ku temu daje najnowsze opracowanie autorów czeskich, poświęcone prawu wodnemu. Autorzy ujęli swe rozważania w następujących rozdziałach:

1. Wprowadzenie do problematyki prawa wodnego (Z. Horaček, M. Sobotka, Z. Strnad): pojęcie, źródła i system prawa wodnego, wybrane etapy $\mathrm{z}$ historii prawa wodnego, instrumenty prawa wodnego, międzynarodowe i unijne aspekty prawa wodnego.

2. Używanie wód (Z. Horaček, J. Nietscheova, Z. Strnad, V. Vytejčkova): rodzaje wód, charakter prawny wód i prawa do nich, postępowanie z wodami, inne używanie wód, rybactwo, zaopatrzenie w wodę pitną, odprowadzanie i oczyszczanie ścieków.

3. Budowle wodne i wodnogospodarcze prace ziemne (Z. Horaček, A. Klikova, Z. Strnad): zakres budowli wodnych, realizacja budowli wodnych, obowiązki związane z budowlami wodnymi i ochrona budowli wodnych, wodnogospodarcze prace ziemne.

4. Ochrona wód i ochrona przed szkodliwymi oddziaływaniami wód (Z. Horaček, J. Nietcheova, M. Sobotka, V. Vytejčkova): ochrona stosunków wodnych i zasobów wodnych, ochrona ilościowa wód, ochrona jakości wód, zarządzanie ciekami wodnymi, administracja dorzeczy, sytuacje powodziowe i kryzysowe, związana z wodami legislacja ochrony środowiska, szkody ekologiczne w wodach.

5. Administracja publiczna w gospodarce wodnej (A. Klikowa, M. Sobotka, Z. Strnad): urzędy wodnoprawne, Czeska Inspekcja Środowiska, postępowanie wodnoprawne, akty administracyjne o charakterze ogólnym.

Opracowanie kończą aneksy, wykaz źródeł, streszczenie angielskie i informacja o autorach.

Zrozumiałe jest, że porównanie całości czeskiego i polskiego prawa wodnego wymagałoby bardzo obszernego dzieła. Nasz zamiar jest znacznie skromniejszy, zajmiemy się tylko kilkoma podstawowymi zagadnieniami dającymi obraz czeskiego prawa wodnego na tle rozwiązań polskich. Zaliczamy do nich: historię prawa wodnego, źródła prawa wodnego, miejsce pra- 
wa wodnego $\mathrm{w}$ systemie prawa, instrumenty prawa wodnego, status prawny wód, administrację wodną. Świadomie i celowo poza zakresem rozważań pozostawiamy instytucje materialnego prawa wodnego, wychodząc z założenia, że one muszą być podobne, gdyż czerpią z tych samych dyrektyw unijnych, a analiza podobieństw i różnic wymagałaby kilkusetstronicowej monografii.

\section{HISTORIA CZESKIEGO PRAWA WODNEGO}

Autorzy monografii czeskiej wskazują, że prawo wodne wywodzi się z prawa rzymskiego. Pierwsze czeskie akty legislacyjne sięgają czasów Karola IV, kiedy został powołany urząd królewskiego hrabiego do spraw żeglugi. Wtedy cieki wodne uznane za drogi wodne traktowano jako przedmiot książęcego, następnie królewskiego regale. Ale już Władysławowskie urządzenie ziemskie z 1500 r. uznało spławne rzeki za przedmiot powszechnego użytku, po czym znowelizowane przez Ferdynanda II w 1627 r. rozszerzyło taki użytek na wszystkie rzeki.

W 1811 r. został wydany powszechny kodeks cywilny, w którym znajdowały się też postanowienia wodnoprawne. Zróżnicował on wody publiczne i prywatne. Wszystkie spławne rzeki zostały zaliczone do publicznych, z których mogli korzystać wszyscy. Regulamin młyński z 1814 r. uchylił stare regale młynne i pozwolił każdemu starać się o pozwolenie na wzniesieniu budowli lub urządzenia wodnego.

Pierwszą pełną kodyfikację prawa wodnego na obszarze Austro-Węgier wprowadzono ustawą wodną z 1869 r. Była ona pomyślana jako ustawa ramowa. Austriackie ministerstwo rolnictwa wydało tzw. jednolite podstawy ziemskich ustaw wodnych, na których podstawie wydano w 1870 r. osobne ustawy wodne dla Czech, Moraw i Śląska. Obowiązywały one bez większych zmian w okresie międzywojennym, w Protektoracie Czech i Moraw oraz po II wojnie światowej aż 1/2014 do 1 stycznia 1955 r., kiedy weszła w życie pierwsza czecho- 
słowacka ustawa o gospodarce wodnej ${ }^{2}$, oparta na planowaniu. Były już w niej wzmianki o ochronie wód. Po kilkunastu latach została ona zastąpiona ustawą z 1973 r. o wodach ${ }^{3}$ jako ustawą federalną. To już nie była ustawa o gospodarce wodnej, ale ustawa o wodach, czym ustawodawca dał wyraz temu, że ma ona zakres szerszy. Na poziomie republik wydano odrębne ustawy o administracji państwowej w gospodarce wodnej, w Czechach była to ustawa z $1974 \mathrm{r}^{4}{ }^{4} \mathrm{~W}$ ten sposób doszło do rozdzielenia problematyki materialnej prawa wodnego (ustawa z 1973 r.) i administracji wodnej (ustawa z 1974 r.). Ustawa wodna z 1973 r. wychodziła z podstawowej dla ustroju socjalistycznego zasady, że gospodarka ma być kierowana planowo. Ustawa ta, inaczej niż to jest w ustawodawstwie obowiązującym, zawierała także podstawowe przepisy dotyczące publicznych wodociągów i publicznej kanalizacji.

Ten stan prawny utrzymał się do 1 stycznia 2002 r., kiedy obie ustawy zostały zastąpione obowiązującą ustawą wodną z 28 czerwca 2001 r. ${ }^{5}$ Celem tej ustawy jest zwłaszcza ochrona wód powierzchniowych i podziemnych, gospodarne wykorzystywanie zasobów wodnych, zachowanie i ulepszanie jakości wód, łagodzenie niekorzystnych skutków suszy, a od noweli, która weszła w życie 1 sierpnia 2010 r., akcent został położony na zaopatrzenie ludności w wodę pitną, które jest priorytetowe w stosunku do innych dozwolonych sposobów postępowania z wodami. Potrzeba przyjęcia nowej ustawy wodnej była dyktowana także koniecznością transformacji licznych dyrektyw europejskich z ramową dyrektywą wodną 2000/60/WE na czele. Autorzy akcentują, że finalne przyjmowanie dyrektywy ramo-

2 Zakon č. 11/1955 Sb., o vodnim hospodařstvi. Czytelnikowi polskiemu należy się wyjaśnienie, jak powołuje się czeskie akty prawne. Otóż po literze „č" (skrót od čisla, tj. numeru) następuje pozycja, pod którą akt został opublikowany w oficjalnym zbiorze aktów prawnych (Sbirka zakonů), łamana przez rok publikacji i zakończona literami „Sb.” (skrótowcem tego zbioru aktów prawnych).

3 Zakon č. 138/1973 Sb., o vodach (vodni zakon).

4 Zakon č. 130/1974 Sb., o statni spravě ve vodnim hospodařstvi.

5 Zakon č. 254/2001 Sb., o vodach a o změně některych zakonů (vodni zakon). 
wej w październiku 2000 r. przebiegało równolegle z dyskusją nad projektem ustawy czeskiej, co znalazło wyraz także w tym, że wpisano do niej trwale zrównoważony rozwój w gospodarce wodnej.

Kończąc zwięzłe uwagi historyczne, autorzy czescy oceniają, że zmiany $\mathrm{w}$ tej dziedzinie prawa nie następują rewolucyjnie. Kontynuacja rozwoju prawa wodnego jest (w przeważającej mierze) zachowana, ale każdy etap rozwojowy przynosi coś nowego.

\section{HISTORIA POLSKIEGO PRAWA WODNEGO}

Początki nowoczesnego prawa wodnego w Czechach i Polsce są podobne. W obu krajach wskazuje się bowiem na szczególną rolę ustawy austriackiej z 1869 roku, która uchodzi za pierwszą, która zasłużyła na miano „prawa wodnego” w dzisiejszym rozumieniu. Różnica jest natomiast taka, że polski ustawodawca korzystał w okresie międzywojennym także ze wzorców niemieckich, a przede wszystkim z systemu regulacyjnego stworzonego przepisami pruskiej ustawy wodnej z $1913 \mathrm{r}$. W rezultacie pierwsza polska ustawa wodna z dnia 19 września 1922 r. zdradza wpływy austriackie oraz pruskie. Uregulowała własność wód, ich użytkowanie, utrzymanie i regulację wód, ochronę od powodzi oraz zagadnienia ustrojowe ${ }^{6}$.

Zmiany polityczne, jakie zaszły w Polsce po II wojnie światowej, wymusiły potrzebę dostosowania do nowych warunków ustrojowych także prawa wodnego. Prace nad ustawą, dostosowaną do realiów socjalistycznego państwa, trwały od połowy 1957 r. Nowa ustawa - Prawo wodne została uchwalona w dniu 30 maja 1962 r. ${ }^{7}$, czyli siedem lat później niż w Czechosłowacji.

6 Zob. Z. Mikulski, Osiemdziesiąt lat polskiego prawa wodnego 1922-2002, „Gospodarka Wodna” Nr 11/2003, s. 448 i n.

7 Dz.U. Nr 34, poz. 158 i z 1971 r. Nr 12, poz. 115. 
Mimo systemowego podobieństwa do ustawy z 1922 r., pojawiły się $\mathrm{w}$ niej elementy właściwe państwu i gospodarce socjalistycznej. Przede wszystkim już w art. 1 zamieszczono deklarację, że wody stanowią własność państwa, o ile ustawa nie stanowi inaczej. Z prywatną własnością gruntu powiązano tylko powierzchniowe wody stojące oraz wody w studniach i rowach. Akcenty ustrojowe zostały także zawarte w przepisach ogólnych o hierarchii celów w gospodarowaniu wodami (art. 3, 22) oraz o prowadzeniu planowej gospodarki wodnej (art. 4, 23). W ustawie z 1962 r. zadania z zakresu gospodarki wodnej zostały przydzielone organom administracji państwowej, której kształt uwzględniał specyfikę ustroju państwa socjalistycznego (ustrój administracji ulegał zresztą w latach sześćdziesiątych i siedemdziesiątych istotnym przeobrażeniom).

Kolejną, trzecią ustawą obejmującą problematykę gospodarki wodnej była ustawa z dnia 24 października 1974 r. - Prawo wodne ${ }^{8}$. Różniła się ona od poprzedniej zarówno szerszym zakresem przedmiotowym, jak i zmienionym układem treści. Najistotniejsze zmiany do niej wprowadzone polegały na objęciu przepisami ustawy materii wcześniej w prawie wodnym nieregulowanych (np. zaopatrzenie ludności w wodę i odprowadzanie ścieków. Usunięto natomiast z ustawy przepisy szczególne o postępowaniu wodnoprawnym.

Ważnym momentem, inicjującym zmiany $\mathrm{w}$ regulacji prawnej gospodarki wodnej, stały się przemiany polityczne dokonane $\mathrm{w}$ Polsce na przełomie lat osiemdziesiątych i dziewięćdziesiątych. Wywołały one bowiem potrzebę dostosowania systemu prawnego do nowych warunków prawno-ustrojowych. Chodziło przede wszystkim o stworzenie podstaw funkcjonowania gospodarki rynkowej (przy odejściu od systemu centralnego planowania społeczno-gospodarczego) oraz o przebudowę administracji, m.in. w kontekście pojawienia się nowych podmiotów samorządu terytorialnego. Odrębnym motywem przemian stało się dostosowywanie polskiego prawa do wymagań wynikających z ówczesnego prawa wspólnotowego z uwagi na dążenie Polski do członkostwa we Wspólnotach Europejskich.

8 Dz.U. Nr 38, poz. 230 ze zm. 
Po wieloletnich pracach studialnych i legislacyjnych w dniu 18 lipca 2001 r. uchwalono obecnie obowiązującą ustawę - Prawo wodne9. Wydzielono z jej zakresu problematykę zbiorowego zaopatrzenia $\mathrm{w}$ wodę i zbiorowego odprowadzania ścieków, która stała się treścią odrębnej ustawy sektorowej z dnia 7 czerwca 2001 r. $^{10}$ Podobnie stało się z problematyką bezpośredniej ochrony przed powodzią, regulowaną w ustawie z dnia 18 kwietnia 2002 r. o stanie klęski żywiołowej ${ }^{11}$.

W systematyce ustawy, liczącej pierwotnie 220 artykułów, znacznie zostały rozbudowane przepisy o zarządzaniu zasobami wodnymi, które obejmują problematykę ustrojową, planowanie w gospodarowaniu wodami, pozwolenia wodnoprawne, instrumenty ekonomiczne (chodzi o opłaty i należności, rodzajowo inne od opłat i kar pieniężnych za pobór wody i odprowadzanie ścieków, uregulowanych w ustawie - Prawo ochrony środowiska), a także kataster i monitoring. Ustawa nie wprowadziła gruntownych zmian w takich kwestiach, jak korzystanie z wód, pozwolenia wodnoprawne (wyjątkiem jest pozwolenie na wprowadzanie ścieków zawierających substancje szczególnie szkodliwe dla środowiska wodnego do urządzeń kanalizacyjnych) czy spółki wodne. Zwrócić natomiast trzeba uwagę na uregulowania dotyczące własności wód. Ustawodawca odchodzi od modelu jednolitej własności Skarbu Państwa, charakterystycznej dla ustawy z 1962 i 1974 r., powraca natomiast do rozwiązań znanych z ustawy wodnej z $1922 \mathrm{r}$.

Dokonując krótkiego podsumowania sformułować można wnioski zbliżone do konkluzji autorów czeskich. Tak więc istnieje pewien kanon myślenia o prawie wodnym, który jest w stanie przetrwać zmiany ustrojowe. W Polsce został on wyznaczony przez ustawę z 1922 r. Współcześnie nowym elementem kształtującym system prawa wodnego jest rosnąca rola prawa europejskiego. Wpływ ten będzie się utrzymywał także

9 Tekst ogłoszony: Dz.U. Nr 115, poz. 1229, tekst jedn. Dz.U. z 2012 r., poz. 145 ze zm.

10 Tekst jedn. Dz.U. z 2006 r. Nr 123, poz. 858 ze zm.

11 Dz.U. Nr. 62, poz. 558 z późn. zm. 
w przyszłości, prowadząc do znacznego upodobnienia, w skali europejskiej, rozwiązań służących gospodarce wodnej ${ }^{12}$.

\section{POJĘCIE, ŹRÓDŁA I SYSTEM PRAWA WODNEGO}

Podstawą systemu prawnego Republiki Czeskiej jest Konstytucja uchwalona 16 grudnia 1992 r. $^{13}$, kiedy już było wiadomo, że z dniem 1 stycznia 1993 r. nastąpi podział Czechosłowacji na Republiki Czeską i Słowacką, oraz przyjęta jeszcze w okresie federacji 9 stycznia 1991 r. Karta Podstawowych Praw i Wolności, która ustawą konstytucyjną z tegoż 16 grudnia 1992 r. została uznana za część konstytucyjnego systemu prawnego Republiki Czeskiej14.

Autorzy omawianej monografii wychodzą z założenia, że prawo wodne jest częścią składową systemu prawa publicznego, ale niektóre instytucje prawa wodnego mają charakter prywatnoprawny, np. cywilnoprawna regulacja odpowiedzialności za szkodę, a stosunki powstające przy eksploatacji wodociągów i kanalizacji dla potrzeb publicznych mają głównie charakter handlowoprawny.

Prawo wodne nie tworzy samodzielnej dziedziny prawa, ale należy do części szczególnej prawa administracyjnego, zwłaszcza jeśli chodzi o regulację budowlaną i przeciwpowodziową, po części zaś do prawa środowiska w przepisach dotyczących postępowania z wodami i ochrony wód.

Podstawowym źródłem prawa wodnego jest wspominana już ustawa wodna z $2001 \mathrm{r}$. Od siebie dodamy, że jest to obszerny akt prawny składtający się ze 159 paragrafów $^{15}$ (137 w tekście

12 Zob. J. Rotko, Linia rozwojowa polskiego prawa wodnego, [w:] Prawo i polityka w ochronie środowiska. Studia z okazji 40-lecia pracy naukowej Jerzego Sommera, Wrocław 2006, s. 141 i n.

13 Ustavni zakon č. 1/1993 Sb., Ustava Česke republiky.

14 Ustavni zakon č. 2/1993 Sb., o vyhlašeni Listiny zakladnich prav a svobod jako současti ustavniho pořadku Česke republiky.

15 W ustawach czeskich podstawową jednostką redakcyjną jest paragraf, który może się dzielić na ustępy, te zaś na litery. Artykuły (članky) występują w konstytucji i w ustawach konstytucyjnych. 
pierwotnym plus 22 dodane $\mathrm{z}$ oznaczeniem literowym $\mathrm{w}$ trakcie nowelizacji, których w 12-letnim okresie obowiązywania było 21). Część pierwsza została podzielona na trzynaście rozdziałów:

I. $\quad$ Przepisy wprowadzające (§ 1-4)

II. Postępowanie z wodami (§ 5-20)

III. Stan wód powierzchniowych i podziemnych (§ 21-22)

IV. Planowanie wodne (§ 23-26)

V. Ochrona stosunków wodnych i zasobów wodnych (§ 27-42)

VI. Cieki wodne (§ 48-53)

VII. Administracja dorzeczy (§ 54)

VIII. Budowle wodne (§ 55-62)

IX. Ochrona przez powodziami (§ 63-87)

X. Opłaty (§ 88-103)

XI. Wykonywanie administracji publicznej (§ 104-115)

XII. Delikty administracyjne (§ 116-125l)

XIII. Przepisy wspólne i przejściowe (§ 126-127).

Części od drugiej do dziesiątej (§ 128-136) to zmiany w innych ustawach, część jedenasta to jedyny $\S 137$ (wejście w życie - 1 stycznia 2002 r.). Ustawa została opatrzona dwoma załącznikami. Załącznik nr 1 zawiera wykaz substancji szczególnie niebezpiecznych i niebezpiecznych, załącznik nr 2 określa stawki opłat za pobór wód i odprowadzanie ścieków.

Dla realizacji ustawy przyjęto ponad dwadzieścia aktów wykonawczych $\mathrm{w}$ postaci rozporządzeń rządowych (nařizeni vlady) oraz aktów centralnych urzędów wodnoprawnych $\left(\right.$ vyhlašky) ${ }^{16}$. Najnowsze wydanie komentarza do ustawy wod-

16 Czeskie nařizeni to „rozporządzenie”, które rząd może wydać bezpośrednio na podstawie art. 78 Konstytucji, bez upoważnienia ustawowego, aczkolwiek w praktyce ustawy często zawierają delegacje do wydawania rozporządzeń. Czeska vyhlaška to słownikowo „oznajmienie” lub „obwieszczenie”, ale $\mathrm{w}$ języku prawnym to akt normatywny wydawany przez ministerstwa lub inne centralne urzędy administracyjne, dla których niezbędne jest upoważnienie ustawowe. W szczegółach zob. V. Sladeček, Obecne spravni pravo, Praha 2013, s. 81 i n. Komentatorzy Konstytucji piszą, że ukształtowała się taka praktyka, że jeśli już w czasie przygotowywania ustawy przewiduje się potrzebę wydania aktów wykonawczych, to ustawa wyraźnie upoważnia rząd do wydania rozporządzeń wskazując na ich konkretną treść, natomiast tylko na podstawie art. 78 Konstytucji rząd wydaje rozporządzenia w sytuacjach 
nej ${ }^{17}$ wylicza 34 obowiązujące akty wykonawcze, w tym 9 rozporządzeń (wśród nich 3 jeszcze z okresu socjalistycznego, są to rozporządzenia o chronionych obszarach naturalnej akumulacji wód) oraz 25 vyhlašek.

Autorzy monografii wprowadzają pojęcie pomocniczych (podpuirne) źródeł prawa wodnego, do których zaliczają inne ustawy i akty wykonawcze do nich, w szczególności:

- ustawę katastralną z $1992 \mathrm{r}^{18}$ w odniesieniu do wpisywania budowli wodnych i stref ochronnych do katastru nieruchomości,

- ustawę z 2004 r. o postępowaniu administracyjnym ${ }^{19}$ w odniesieniu do postępowań procesowych organów administracyjnych, zwłaszcza urzędów wodnoprawnych, Czeskiej Inspekcji Środowiska i in.,

- ustawę budowlaną z $2006 \mathrm{r} .^{20} \mathrm{w}$ sprawach wydawania pozwoleń na budowle wodne i prace wodnogospodarcze,

- ustawę z 2008 r. o szkodzie ekologicznej²1,

nadzwyczajnych lub pilnych, nieprzewidzianych w czasie przygotowywania ustawy - zob. K. Klima a kolektiv, Komentař k Ustavě a Listině. 1. dil, Plzeń 2009, s. 582. Jeśli chodzi o vyhlašky wydawane przez ministerstwa na podstawie art. 79 ust. 3 Konstytucji, to upoważnienie ustawowe jest niezbędne, ale nie jest konieczne, aby przepis upoważniający definiował całą zakładaną treść przepisu wykonawczego, ponieważ i tak musi się ona mieścić w granicach ustawy i odpowiadać regułom określonym w Konstytucji oraz Karcie Podstawowych Praw i Wolności (tamże, s. 597).

17 Z. Horaček, M. Kral, Z. Strnad, V. Vytejčkova, Vodni zakon. II vydani s podrobnym komentařem po velke novele stavebniho zakona $k$ 1.1.2013, Praha 2013, s. 317-318.

18 Zakon č. 344/1992 Sb., o katastru nemovitosti Česke republiky (katastralni zakon).

19 Zakon č. 500/2004 Sb., spravni řad.

20 Zakon č. 183/2006 Sb., o uzemnim planovani a stavebnim řadu (stavebni zakon).

21 Zakon č. 167/2008 Sb., o předchazeni ekologicke ujmě a o jeji napravě a o změně některych zakonů. 
- ustawę rybacką z 2004 r. $^{22}$ w sprawach wykorzystywania wód powierzchniowych dla hodowli ryb,

- ustawę z 1992 r. o ochronie przyrody i krajobrazu ${ }^{23}$ na przykład w sprawach ochrony cieków wodnych jako znaczących elementów krajobrazu,

- ustawę z 2001 r. o wodociągach i kanalizacji ${ }^{24}$ w sprawach regulacji dziedziny wodociągów i kanalizacji.

Do tego dochodzą tzw. czeskie normy techniczne w rozumieniu ustawy normalizacyjnej z $1997 \mathrm{r}^{25}$ Te normy nie są wprawdzie powszechnie obowiązujące, ale jeżeli zostały przejęte (zezavazněny ${ }^{26}$ ) przez akt prawny, decyzję administracyjną lub akt administracyjny o charakterze ogólnym (opatřeni obecne povahy ${ }^{27}$ ) stają się wiążące i należy się nimi kierować.

\section{POJĘCIE, ŹRÓDEA I SYSTEM POLSKIEGO PRAWA WODNEGO}

W kwestii pojęcia, źródeł i systemu prawa wodnego nie znajdziemy w polskiej nauce prawa zasadniczych odmienności wobec poglądów teoretyków czeskich i trudno się temu dziwić.

22 Zakon č. 99/2004 Sb., o rybnikařstvi, vykonu rybařskeho prava, rybařske straži, ochraně mořskych rybolovnych zdrojů a o změně některych zakonů (zakon o rybařstvi).

23 Zakon č. 114/1992 Sb., o ochraně přirody a krajiny.

24 Zakon č. 274/2001 Sb., o vodovodech a kanalizacich pro veřejnou potřebu a o změně některych zakonů (zakon o vodovodech a kanalizacich).

25 Zakon č. 22/1997 Sb., o technickych požadavcich na vyrobky a o změně a doplněni některych zakonů.

${ }^{26} \mathrm{~W}$ języku czeski zavazny to „wiążący”, a zatem zezavazněny to tyle, co „uznany za wiążacy”.

27 Instytucja wprowadzona przez ustawę z 2004 r. o postępowaniu administracyjnym i definiowana przez nią jedynie „negatywnie” - ani akt normatywny, ani decyzja administracyjna. W istocie chodzi o akt indywidualny co do przedmiotu i generalny co do adresatów. Można do niego sięgnąć tylko wtedy, gdy przepis szczególny możliwość taką przewiduje. Ustawa wodna często przewiduje wydawanie takich opatřeni obecne povahy, w tej formie ustanawia się strefy ochronne, ogranicza się powszechne korzystanie z wód itp. 
Pomimo pewnych odmienności w unormowaniach szczegółowych zarówno czeskie, jak i polskie prawo administracyjne wywodzi się z tych samych tradycji prawa kontynentalnego, pozostając pod wpływem kultury prawnej państw niemieckojęzycznych.

Prawo wodne $\mathrm{w}$ ujęciu przedmiotowym można zatem zdefiniować jako zbiór (zespół) przepisów prawnych, których przedmiotem jest gospodarowanie wodą, rozumiane jako ogół świadomych i celowych działań podejmowanych w celu kształtowania stosunków wodnych, ochrony przed powodzią i suszą, korzystania z zasobów wodnych oraz ich ochrony ilościowej i jakościowej. Zbiór ten przedstawić można jako rozbudowaną strukturę, obejmującą liczne ustawy oraz akty wykonawcze, a także akty prawa miejscowego. W sposób typowy dla kontynentalnego prawa europejskiego tworzy ona układ hierarchiczny, a na jej szczycie znajduje się Konstytucja RP. Bezpośrednich odesłań do gospodarki wodnej w Konstytucji wprawdzie nie ma, ale w art. 5, określającym główne zasady ustrojowe, wskazuje się także na zasadę zrównoważonego rozwoju, jako normę wytyczającą kierunek działania Państwa. Znaczenie tej zasady dla całej gospodarki wodnej potwierdza art. 1 ust. 1 ustawy Prawo wodne. Do źródeł prawa z zakresu gospodarki wodnej zaliczyć trzeba także ratyfikowane umowy międzynarodowe oraz akty prawa europejskiego.

Na system źródeł polskiego prawa gospodarki wodnej składają się, obok ustawy z dnia 18 lipca 2001 r. - Prawo wodne, także - co najmniej - następujące ustawy (oraz oparte na nich akty wykonawcze):

1) ustawa z dnia 27 kwietnia 2001 r. - Prawo ochrony środowiska $^{28}$ jako akt prawny o podstawowym znaczeniu dla ochrony środowiska wywiera wieloraki wpływ na system prawny ochrony wód;

2) ustawa z dnia 7 czerwca 2001 r. o zbiorowym zaopatrzeniu w wodę i zbiorowym odprowadzaniu ścieków, która określa zasady funkcjonowania sektora wodocią-

28 Tekst jedn. z 2008 r, Nr 25, poz. 150 późn. zm. 
gowo-kanalizacyjnego w szerokich ramach zadań własnych gmin;

3. ustawa z dnia 13 września 1996 r. o utrzymaniu czystości i porządku w gminach ${ }^{29}$, podejmująca niektóre kwestie istotne dla komunalnej gospodarki wodno-ściekowej;

4) ustawa z dnia 16 kwietnia 2004 r. o ochronie przyro$\mathrm{dy}^{30}$, której przepisy określają zasady i formy ochrony przyrody, co wywiera także wpływ na sposób i zakres ochrony wód; poza tym ustawa przewiduje dodatkowy instrument administracyjnej kontroli wstępnej, gdyż uzależnia wykonywanie niektórych prac na obszarach przyrodniczo cennych (np. polegających na regulacji wód lub budowie wałów przeciwpowodziowych) od uzyskania specjalnej decyzji wojewody (art. 118);

5) ustawa z dnia z dnia 10 lipca 2007 r. o nawozach i nawożeniu ${ }^{31}$ - mająca znaczenie dla ochrony wód przed emisjami rozproszonymi (niezorganizowanymi) ścieków, zawierających azot i fosfor pochodzenia rolniczego;

6) ustawa z dnia 9 czerwca 2011 r. - Prawo geologiczne i górnicze ${ }^{32}$, która określa m.in. zasady korzystania z solanek, wód leczniczych i termalnych;

7) ustawa z dnia 7 lipca 1994 r. - Prawo budowlane ${ }^{33}$, zawierająca regulacje nakładające się na postanowienia Prawa wodnego o wykonywaniu urządzeń wodnych, choć nie ma tu pełnej symetrii wymagań;

8) ustawa z dnia 18 kwietnia 1985 r. o rybactwie śródlądowym ${ }^{34}$, która reguluje zasady i warunki ochrony, chowu, hodowli i połowu ryb w powierzchniowych wodach śródlądowych;

29 Dz.U. z 2005 r. Nr 236, poz. 2008, z późn. zm.

30 Dz.U. Nr 92, poz. 880 z późn. zm.

31 Dz.U. Nr 147, poz. 1033.

32 Dz.U. Nr 163, poz. 981 z późn. zm.

33 Tekst jedn. z 2010 r. Dz.U. Nr 243, poz. 1623 z późn. zm.

34 Tekst jedn. z 2009 r. Dz.U. Nr 189, poz. 1471 z późn. zm. 
9) ustawa z dnia 21 grudnia 2000 r. o żegludze śródlądowej35, zawierająca unormowania związane $\mathrm{z}$ uprawianiem żeglugi na wodach śródlądowych uznanych za żeglowne;

10) ustawa $z$ dnia 21 marca o obszarach morskich Rzeczypospolitej Polskiej i administracji morskiej ${ }^{36}$, która określa sytuację prawną obszarów morskich RP, pasa nadbrzeżnego oraz organy administracji morskiej i ich kompetencje (m.in. przewiduje, że w wyłącznej strefie ekonomicznej obowiązuje prawo polskie dotyczące ochrony środowiska);

11) ustawa z dnia 16 marca 1995 r. o zapobieganiu zanieczyszczania morza przez statki ${ }^{37}$, który służy przeniesieniu do prawa krajowego postanowień trzech umów międzynarodowych;

12) ustawa z dnia 6 lipca 2001 r. o zachowaniu narodowego charakteru strategicznych zasobów naturalnych kraju $^{38}$, podkreślająca wyłączną własność Skarbu Państwa w stosunku m.in. do wód podziemnych i wód powierzchniowych, a także wód polskich obszarów morskich; nie podlegają one przekształceniom własnościowym, z zastrzeżeniem przepisów zawartych w ustawach szczególnych.

Wzajemne relacje między przepisami tych ustaw kształtują się różnorodnie. Ogólnie przyjąć można, że ustawa - Prawo wodne wyznacza podstawowe zasady gospodarki wodnej, wspólne dla wszystkich jej sektorów. W niektórych przypadkach ustawa - Prawo wodne odsyła do przepisów innych ustaw i określa zakres takiego odesłania.

Tekst jedn. z 2006 r. Dz.U. Nr 123, poz. 857.

Tekst jedn. z 2006 r. Dz.U. Nr 99, poz. 692, z późn. zm.

Dz.U. Nr 97, poz. 1051, zm. Dz.U. z 2003 r. Nr 113, poz.1068. 


\section{INSTRUMENTY PRAWA WODNEGO}

Autorzy omawianego dzieła czeskiego wychodzą z powszechnie przyjętego $\mathrm{w}$ nauce prawa środowiska podziału instrumentów prawnych ${ }^{39}$ na:

1) instrumenty bezpośredniego oddziaływania (nastroje primeho pưsobeni), które nie dają podmiotowi (adresatowi) możliwości wyboru zachowania; do tej grupy zaliczają instrumenty administracyjnoprawne, instrumenty koncepcyjne, umowy administracyjne i inne dobrowolnie przyjęte obowiązki,

2) instrumenty pośredniego oddziaływania (nastroje neprimeho působeni), które dają podmiotowi (adresatowi) możliwość wyboru zachowania; do tej grupy zaliczają przede wszystkim instrumenty ekonomiczne.

W dziedzinie prawa wodnego zajmują się instrumentami administracyjno-prawnymi, sankcyjnymi, koncepcyjnymi i ekonomicznymi, przyjmując następujące założenia:

Instrumenty administracyjno-prawne to zwłaszcza obowiązki nakładane ustawą lub przez organy administracji na podstawie ustawy w formie nakazu, zakazu lub ograniczenia. Tytułem przykładów: ustawowy zakaz bezpośredniego wypuszczania ścieków do wód podziemnych (§38 ust. 7 ustawy wodnej), ustawowy obowiązek rybaka stawowego i użytkownika rewiru rybackiego gospodarować tak, aby nie doszło do pogorszenia jakości wód (§ 12 ust. 7 ustawy rybackiej), ustawowy obowiązek właściciela gruntu, na którym znajdują się koryta cieków wodnych, ścierpieć na swych gruntach budowle wodne wzniesione przed 1 stycznia 2002 r. (§ 50 lit. c ustawy wodnej). Obowiązek nałożony na podstawie ustawy to np. obowiązek dotrzymywania warunków wskazanych w pozwoleniu na postępowanie z wodami ( $९ 9$ ust. 1 ustawy wodnej). Do instrumentów administracyjno-prawnych autorzy zaliczają także pozwolenia, zgody czy opinie urzędów wodnoprawnych, ukierunkowujące

39 M. Damohorsky a kolektiv, Pravo životniho prostředi, Praha 2010, s. $36-47$. 
różne działania z punktu widzenia interesów publicznych chronionych ustawą wodną.

Instrumenty sankcyjne to kary wymierzane przez uprawnione do tego organy, przy czym w zakresie gospodarki wodnej i rybactwa chodzi przede wszystkim o karanie za delikty administracyjne. Tylko na marginesie można do instrumentów sankcyjnych zaliczyć także karanie za przestępstwa, np. za uszkodzenie zasobów wodnych z § 294a kodeksu karnego ${ }^{40}$.

Delikty administracyjne można podzielić na wykroczenia osób fizycznych oraz delikty administracyjne osób fizycznych będących przedsiębiorcami i osób prawnych. Regulacje deliktów administracyjnych znajdują się w rozdziale XII ustawy wodnej, rozdziale VIII ustawy o wodociągach i kanalizacji oraz w rozdziale VIII ustawy rybackiej. Organami właściwymi do wymierzania kar są urzędy wodnoprawne, Czeska Inspekcja Środowiska, Państwowa Administracja Żeglugi oraz organy państwowej administracji rybackiej. Ponadto straż rybacka może wymierzać kary za wykroczenia w postępowaniu mandatowym.

Różnica między odpowiedzialnością tych dwóch grup podmiotów polega na tym, że „zwykłe” osoby fizyczne (nie-przedsiębiorcy) odpowiadają za wykroczenia tylko w razie udowodnienia im winy, podczas gdy odpowiedzialność osób fizycznych-przedsiębiorców i osób prawnych za delikty administracyjne jest odpowiedzialnością obiektywną, bez względu na zawinienie. Sprawca deliktu administracyjnego może się zwolnić od odpowiedzialności, jeżeli wykaże, że dołożył wszelkich wysiłków, jakich można wymagać, aby zapobiec naruszeniu obowiązku prawnego (§ 1251 ust. 1 ustawy wodnej) $)^{41}$. Za wykroczenia osób fizycznych można nałożyć różne sankcje, także ich kombinacje, a to upomnienie, karę pieniężną (pokuta),

40 Zakon č. 40/2009 Sb., trestni zakonik. Przepis § 294a stanowi: „Kto, choćby z rażącego niedbalstwa, wyrządzi szkodę zasobowi wodnemu, dla którego ustanowiono strefę ochronna, tak że zaniknie lub zostanie znacznie osłabiony powód szczególnej ochrony zasobu wodnego, zostanie ukarany pozbawieniem wolności do lat 2".

41 Od siebie dodamy, że czeska nauka o odpowiedzialności administracyjnej wzbogaciła się ostatnio o znakomitą monografię Heleny Praškovej, Zaklady odpovědnosti za spravni delikty, Praha 2013. 
zakaz wykonywania działalności lub przepadek rzeczy, za delikt administracyjny osobie fizycznej-przedsiębiorcy lub osobie prawnej można wymierzyć tylko pokutę.

Instrumenty koncepcyjne określają cele (kierunki) na przyszłość. Są nimi koncepcje, plany, polityki i perspektywy. Nie wpływają one na zachowanie adresatów bezpośrednio, lecz wyznaczają strategiczne limity działań administracji publicznej i stosowania innych instrumentów (np. plany dorzeczy są jednym z podkładów wydania pozwolenia na postępowanie $\mathrm{z}$ wodami).

W dziedzinie gospodarki wodnej chodzi o plany dorzeczy (plany povodi ${ }^{42}$ ) oraz plany opanowywania ryzyka powodzi (plany pro zvladani povodňovych rizik) albo mapy (generel) obszarów odpowiednich dla akumulacji wód powierzchniowych ${ }^{43}$.

W wodociągach mamy jeszcze plany rozwoju wodociągów i kanalizacji. Wszystkie te plany są powiązane nie tylko wzajemnie, ale i z innymi koncepcjami, zwłaszcza z instrumentami planowania przestrzennego.

Autorzy zwracają uwagę na zakres przestrzenny instrumentów koncepcyjnych. Niektóre z nich są sporządzane dla obszaru całego państwa. Przepis $\S 24$ ustawy wodnej w brzmieniu obowiązującym do 31 lipca 2012 r. przewidywał Plan głównych dorzeczy Republiki Czeskiej (Plan hlavnich povodi $\check{C} R$ ), obecnie żadnego ogólnopaństwowego planu gospodarki wodnej nie ma, ale integrującą rolę pełni Polityka rozwoju przestrzennego Republiki Czeskiej (Politika uzemniho rozvoje $\check{C} R$ ). Pozostałe są sporządzane w skali regionalnej: plany do-

${ }^{42}$ W języku czeskim povodi to pojęcie geograficzne oznaczające obszar, z którego rzeka, potok itp. odprowadza wodę, czyli polskie „dorzecze”, natomiast polska „powódź” to w języku czeskim povodeň.

43 Według § 28a czeskiej ustawy wodnej powierzchnie morfologicznie, geologicznie i hydrologicznie odpowiednie dla akumulacji wód powierzchniowych i zmniejszenia niekorzystnych skutków powodzi i suszy można dla ich ochrony obszarowej przed innymi działaniami wyznaczyć w Polityce rozwoju przestrzennego i w dokumentacji planowania przestrzennego jako obszary chronione dla akumulacji wód powierzchniowych. Mapę (Generel) takich obszarów sporządza Ministerstwo Rolnictwa w porozumieniu z Ministerstwem Środowiska. Mapa (Generel) jest podstawą planu polityki rozwoju przestrzennego i dokumentacji planowania przestrzennego. 
rzeczy i plany opanowywania ryzyka powodzi dla poszczególnych dorzeczy, plany rozwoju wodociągów i kanalizacji dla poszczególnych krajów.

Instrumenty ekonomiczne autorzy dzielą na dwa rodzaje:

1) motywujące pozytywnie (pozitivně motivačni), jeżeli podmiot otrzyma w ramach dotacji czy innego wsparcia ze źródeł publicznych celowo związane środki finansowe, aby działał w wyznaczonym $\mathrm{z}$ góry celu (np. rewitalizacja cieku wodnego dla ochrony ekosystemu),

2) stymulujące negatywnie (negativně stimulačni), jeżeli podmiot płaci za szkodliwe (aczkolwiek ustawą z różnych powodów dozwolone) działania, tym mniej, im lepiej się zachowuje; w gospodarce wodnej są to opłaty za pobór wód oraz odprowadzanie ścieków.

\section{INSTRUMENTY POLSKIEGO PRAWA WODNEGO}

Wszechstronne analizowanie prawnych środków działania, przy pomocy których przede wszystkim organy administracji publicznej (choć nie tylko) zarządzają zasobami wodnymi, jest ważnym zadaniem nauki prawa. Jednym z narzędzi temu celowi służących jest pojęcie „instrumentów prawnych”, które ma charakter doktrynalny. Zauważyć jednak należy, że także bezpośrednio $\mathrm{w}$ samej ustawie sformułowano katalog takich środków, nazywanych przez polskiego ustawodawcę „instrumentami zarządzania zasobami wodnymi" (art. 2 ust. 2). Zamieszczone $\mathrm{w}$ tym artykule pięciopunktowe wyliczenie nie jest jednak ani kompletne, ani całkiem ścisłe.

Do najważniejszych typów instrumentów w rozumieniu doktrynalnym zaliczyć w każdym bądź razie należy instrumenty administracyjnej kontroli wstępnej i bieżącej, instrumenty planowe, instrumenty obszarowe oraz środki finansowo-prawne. Pokrywają się one z instrumentami wskazanymi przez autorów czeskich, nawet jeśli występują pewne odmienności w ich kategoryzacji i nazewnictwie. 
Instrumenty administracyjnej kontroli wstępnej to pozwolenia wodnoprawne, niektóre inne decyzje przewidziane Prawem wodnym oraz zgłoszenia przewidziane w ustawie - Prawo ochrony środowiska. Poprzedzają one podjęcie korzystania z wód lub wykonywanie innych działań, wyodrębnionych w systematyce ustawy. Lista przypadków, gdy pozwolenie jest wymagane, tworzy treść art. 122 ust. 1 i obejmuje dziesięć pozycji. Przypadki, gdy pozwolenie nie jest wymagane, określa art. 124 i jest ich 11 .

Instrumenty administracyjnej kontroli bieżącej zostały w znacznej mierze wyeksponowane za sprawą wprowadzonego do Prawa wodnego po raz pierwszy rozdziału „Kontrola gospodarowania wodami". Zakres kontroli został ustalony w art. 156 i obejmuje 15 przypadków (między innymi korzystanie z wód, realizacje planów i programów, ochronę wód przed zanieczyszczeniem, utrzymywanie wód oraz urządzeń wodnych, zabezpieczenie przed powodzią).

Wyciąganie konsekwencji z ustalonych w trakcie kontroli nieprawidłowości należy już do odrębnej grupy instrumentów. Stosowanie sankcji zaliczyć bowiem trzeba do instrumentów represyjnych o zróżnicowanym zakresie przedmiotowym i charakterze (np. dokonywanie zmian w pozycji prawnej podmiotu poddanego kontroli poprzez stwierdzenie wygaśnięcia pozwolenia wodnoprawnego, jego cofnięcie lub ograniczenie - zarówno bez odszkodowania, jak i za odszkodowaniem, jeżeli jest to uzasadnione interesem społecznym albo ważnymi względami, unieruchomienie zakładu lub jego części). Można też wystąpić o pociągnięcie do odpowiedzialności karnej z tytułu przestępstwa lub wykroczenia.

Mocno rozbudowaną grupę tworzą w ustawie - Prawo wodne instrumenty planistyczne, które wchodzą do praktyki administracyjnej w różnych formach prawnych. W ustawie przewidziane zostały następujące rodzaje zróżnicowanych formalnie i materialnie dokumentów planistycznych:

1) program wodno-środowiskowy kraju, z uwzględnieniem podziału na obszary dorzeczy (art. 113 ust. 1 pkt 1) - opracowywany przez Prezesa KZGW w uzgodnieniu z ministrem właściwym do spraw środowiska i gospodarki wodnej (art. 119 ust. 1); 
2) plan gospodarowania wodami na obszarze dorzecza (art. 113 ust. 1 pkt 1a) - opracowywany przez Prezesa Krajowego Zarządu Gospodarki Wodnej w uzgodnieniu z ministrem właściwym do spraw gospodarki wodnej, a zatwierdzany przez Radę Ministrów i ogłaszany w Dzienniku Urzędowym „Monitor Polski” (art. 119 ust. 3);

3) plan zarządzania ryzykiem powodziowym (odrębne dla obszarów dorzeczy i dla regionów wodnych), przygotowywane na podstawie art. $88 \mathrm{~h}$ ust. 1 przez Prezesa KZGW w uzgodnieniu z ministrem właściwym do spraw gospodarki wodnej (dla dorzecza) lub dyrektora regionalnego zarządu gospodarki wodnej (dla regionu wodnego na podstawie art. 88h ust. 2),

4) plan przeciwdziałania skutkom suszy na obszarze dorzecza (art. 88s), opracowywane w takim trybie jak plan zarządzania ryzykiem powodziowym dla obszaru dorzecza,

5) warunki korzystania z wód regionu wodnego (art. 113 ust. 1 pkt 4) - ustalane w drodze aktu prawa miejscowego (rozporządzenia) przez dyrektora regionalnego zarządu gospodarki wodnej, po ich uzgodnieniu z Prezesem Krajowego Zarządu Gospodarki Wodnej (art. 120 ust. 1);

6) sporządzane $\mathrm{w}$ miarę potrzeby warunki korzystania $\mathrm{z}$ wód zlewni, tj. fragmentu regionu wodnego (art. 113 ust. 1 pkt 5) - ustalane jak wyżej.

Poza strukturą planów określoną expresis verbis w art. 113 ust. 1 pozostaje jeszcze krajowy program oczyszczania ścieków komunalnych sporządzany przez ministra właściwego do spraw środowiska, zatwierdzany przez Radę Ministrów w drodze uchwały (art. 43 ust. 3) oraz program działań mających na celu ograniczenie odpływu azotu ze źródeł rolniczych, będący jednym $\mathrm{z}$ trzech istniejących w polskim prawie programów naprawczych, mających ogólne oparcie w art. 84 ustawy - Prawo ochrony środowiska (program taki sporządzany jest i zatwierdzany przez dyrektora regionalnego zarządu gospodarki wod- 
nej w drodze rozporządzenia - art. 47 ust. 7) ${ }^{44}$. Istnieją również, tak jak w Czechach, plany rozwoju sieci wodociągowej i kanalizacyjnej, ale nie należy ich zaliczać do materii prawa wodnego.

Jeśli chodzi o instrumenty ekonomiczne oraz finansowo-prawne to stwierdzić należy, że ustawa - Prawo wodne z 2001 r. została dość mocno (w stosunku do ustawy z 1974 r.) okrojona z przepisów o opłatach i karach pieniężnych za korzystanie z wód i urządzeń wodnych. Wynika to z faktu konsolidacji tych instrumentów w ramach ustawy - Prawo ochrony środowisko.

W ustawie pozostawiono natomiast „należności” za korzystanie ze śródlądowych dróg wodnych oraz urządzeń wodnych stanowiących własność Skarbu Państwa, a usytuowanych na śródlądowych wodach powierzchniowych. Poza tym ustawa Prawo wodne przewiduje trzy rodzaje nowych opłat (opłaty za użytkowanie gruntów pokrytych wodami, stanowiących własność Skarbu Państwa, opłaty za oddanie w użytkowanie obwodów rybackich, opłaty za przygotowywanie i udostępnianie danych $\mathrm{w}$ innych formach niż określone $\mathrm{w}$ przepisach ustawy Prawo ochrony środowiska, regulujących zasady dostępu do informacji o środowisku i jego ochronie).

\section{STATUS PRAWNY WÓD}

Czeska ustawa wodna przyjmuje podział wód na powierzchniowe i podziemne. Według §2 ust. 1 wodami powierzchniowymi są wody naturalnie występujące na powierzchni ziemi; nie tracą tego charakteru, jeżeli płyną przez czasowo zakryte odcinki, naturalne wydrążenia pod powierzchnią ziemi albo w urządzeniach nadziemnych. Autorzy zaliczają do nich cieki wodne, wody w młynówkach, zbiornikach wodnych, stawach, zbiornikach nad jazami, w kałużach po deszczu, w pokrywie śniegowej, w okapach domów, w oddzielnych deszczowych (opadowych) kanalizacjach, a także np. wody w wyeksploato-

44 Zob. K. Karpus, Planowanie w gospodarowaniu wodami, [w:] Wybrane problemy prawa wodnego (red. B. Rakoczy), Warszawa 2013, s. 158 i n. 
wanych wyrobiskach górniczych, żwirowiskach lub kamieniołomach. Według § 2 ust. 2 wodami podziemnymi są wody naturalnie występujące pod powierzchnią ziemi w paśmie nasycenia w bezpośredniej styczności ze skałami; za wody podziemne uznaje się też wody płynące podziemnymi systemami drenażowymi oraz wody w studniach. Wody kopalniane mogą być powierzchniowymi lub podziemnymi, w zależności od regulacji szczególnych.

Autorzy omawianej monografii uznają wody, tak jak zostały zdefiniowane w $\S 2$ ust. 1 i 2, za rzeczy szczególne (zvlastni věci), które nie są przedmiotem własności, co wynika stąd, że naturalnie występujące wody ze względu na niemożliwość zawładnięcia (neovladatelnost) nie mogą być przedmiotem praw rzeczowych, przede wszystkim prawa własności. Zwracają uwagę, że w doktrynie czeskiej toczą się długie spory, czy chodzi o rzeczy niczyje (věci niči, łac. res nullius), jak to ujmował projekt obowiązującej ustawy wodnej, czy o tzw. rzeczy poza obrotem ( $t z v$. věci „mimo obchodovani”, łac. res extra commercium), czy też należy odrzucić obie te koncepcje ze względu na ich niewłaściwe używanie. Autorzy to pytanie jedynie stawiają, ale nie odpowiadają na nie, ograniczając się do przytoczenia fragmentu $\S 3$ ust. 1 ustawy wodnej, według którego wody powierzchniowe i podziemne nie są przedmiotem własności i nie są przynależnością gruntów, na których lub pod którymi występują. Tę regulację ilustrują przykładem wody w studniach. Kończą uwagą, że własność wód nie może należeć ani do państwa, ani do gminy, ani do właściciela gruntu, ani do właściciela budowli wodnej.

Kolejny ust. 2 w $\S 3$ ustawy wodnej stanowi, że za wody powierzchniowe i podziemne nie uważa się wód, które zostały z nich odebrane. Tę regulację autorzy opatrują komentarzem, że wody odebrane są przedmiotem własności tego, kto je odebrał, lub tego, dla kogo zostały odebrane. Do rzeczywistego zawładnięcia (ovladnuti) wodą dochodzi dopiero wtedy, kiedy np. woda została nabrana do naczynia lub wniknie do pompy itp. W tym momencie przestaje być z prawnego punktu widzenia wodą i staje się wodą „odłączoną”, która może być przedmiotem własności, może być rozprowadzana i sprzedawana jak każdy to- 
war. Faktycznie także wody odebrane $\mathrm{z}$ wód powierzchniowych lub podziemnych bezprawnie (bez wymaganego pozwolenia) przestają być wodami powierzchniowymi lub podziemnymi. Prawa do wód powierzchniowych lub podziemnych mogą wynikać tylko z ustawy wodnej lub ważnych pozwoleń właściwych urzędów wodnoprawnych albo poprzednich regulacji prawnych utrzymanych w mocy. W części historycznej autorzy wspominają o studniach wybudowanych bez żadnych pozwoleń przed rokiem 1955, co do których rozporządzenie z 1956 r. przesądziło, że korzystanie $\mathrm{z}$ nich nadal będzie uznawane za korzystanie powszechne.

\section{STATUS PRAWNY WÓD W ŚWIETLE PRZEPISÓW POLSKICH}

W polskiej ustawie punktem wyjścia jest przeprowadzony w art. 5 ust. 1 i 2 dwojaki podział na wody powierzchniowe i podziemne oraz na wody śródlądowe i wody morskie (ten drugi podział był w ustawie czeskiej z oczywistych względów zbędny). W kategorii wód morskich mieszczą się wody morza terytorialnego i morskie wody wewnętrzne. Przepisy ustawy stosuje się co do zasady do wód śródlądowych oraz morskich wód wewnętrznych (art. 7 ust. 1), natomiast do wód morza terytorialnego tylko $\mathrm{w}$ zakresie planowania $\mathrm{w}$ gospodarowaniu wodami, ochrony przed zanieczyszczeniem ze źródeł lądowych oraz przed powodzią, a w pozostałym zakresie w przypadkach w niej określonych (art. 7 ust. 2).

Zakres przedmiotowy wód powierzchniowych wydaje się węższy niż w ustawie czeskiej, albowiem swoiście potraktowano wody w urządzeniach wodnych (przede wszystkim w stawach, rowach i innych urządzeniach melioracyjnych), do których przepisy polskiej ustawy o korzystaniu z wód stosuje się tylko „odpowiednio". Taki sam wniosek dotyczy wód znajdujących się w zagłębieniach terenu powstałych w wyniku działalności człowieka, ale innych niż staw (art. 5 ust. 4). Z polskiej ustawy nie wynika także, aby jej przepisy miały znaleźć zastosowanie 
do wód opadowych z chwilą ich połączenia się z powierzchnią ziemi (z wyjątkiem zanieczyszczonych wód opadowych i roztopowych, uznanych za ściek).

Natomiast podobnie jak w ustawie czeskiej do wód objętych przepisami ustawy nie zalicza się wód zgromadzonych za pomocą urządzeń oraz instalacji technicznych niebędących urządzeniami wodnymi (art. 8 ust. 2), czyli wód „odłączonych” w terminologii czeskiej.

Istotne różnice widać w doktrynalnym podejściu do prawnej natury własności wody. Teoretycy czescy odrzucają koncepcję, aby woda mogła stanowić czyjąkolwiek własność, co przypomina podejście wypracowane jeszcze w prawie rzymskim. Z kolei polski ustawodawca nie wahał się uznać w art. 10 ust. 1 wody za własność (Skarbu Państwa, innych osób prawnych albo osób fizycznych), a równocześnie przydać niektórym z nich walor „wód publicznych”, za sprawą którego nie podlegają one obrotowi cywilnoprawnemu, z wyjątkiem przypadków określonych w ustawie (chodzi o oddawanie wód w użytkowanie rybackie). Inaczej niż w prawie czeskim własność gruntu można rozciągnąć także na powierzchniowe wody stojące oraz wody w rowach. Własność jest co prawda rozumiana cywilistycznie, ale nie jest to własność rzeczy w rozumieniu Kodeksu cywilnego. W tej sytuacji proponuje się mówić po prostu o własności wód w rozumieniu ustawy - Prawo wodne ${ }^{45}$.

\section{ADMINISTROWANIE CIEKAMI WODNYMI I DORZECZAMI}

Pojęcie cieku wodnego zostało zdefiniowane w § 43 ust. 1 ustawy wodnej jako wody powierzchniowe płynące własnym spadem $\mathrm{w}$ korycie trwale lub $\mathrm{w}$ przeważającej części roku, w tym wody sztucznie spiętrzone. Ich częścią składową są także wody w martwych odnogach i w odcinkach przejściowo biegną-

45 Zob. E. Gniewek, Prawo rzeczowe, Warszawa 2010, s. 70. 
cych naturalnymi jamami pod powierzchnią ziemi lub odcinkami zakrytymi. Jak wskazują autorzy, w Republice Czeskiej dzieli się je znaczące cieki wodne (vyznamne vodni toky), których wykaz znajduje się w odpowiednim akcie wykonawczym ${ }^{46}$ oraz pozostałe drobne cieki wodne (drobne vodni toky). Łączna długość znaczących cieków wodnych to ok. 15500 km, a długość wszystkich cieków wodnych na terytorium Republiki Czeskiej to ok. 114 tys. $\mathrm{km}$.

Każdy ciek wodny ma swego administratora, tj. podmiot, który się o niego stara, zarządza nim. Administrację znaczących cieków wodnych sprawują z mocy ustawy administratorzy dorzeczy. Z mocy odrębnej ustawy o dorzeczach ${ }^{47}$ są nimi mające status przedsiębiorstw państwowych administracje pięciu dorzeczy: Łaby, Morawy, Odry, Ohrzy i Wełtawy. Administrację drobnych cieków sprawują różne podmioty, mogą nimi być gminy, osoby fizyczne lub prawne, organizacyjne komórki państwa, przedsiębiorstwa państwowe, zarządy parków narodowych. Każdy ciek wodny ma swego administratora, którego łatwo znaleźć w ewidencji cieków wodnych. Administratorzy cieków nie są organami administracji wodnej, lecz z nimi współpracują.

\section{ADMINISTROWANIE CIEKAMI WODNYMI I DORZECZAMI W POLSCE}

Ustawowy system zarządzania wodami oparty jest w Polsce na nieco innej zasadzie niż w Czechach. Po pierwsze, nie ma podziału cieków na dwie podstawowe kategorie (znaczące i pozostałe) z uwagi na ich znaczenie wodno-gospodarcze. Po drugie, określając zadania i kompetencje z zakresu szeroko rozumianego zarządu wodami, wydzielono krąg uprawnień właścicielskich oraz krąg uprawnień reglamentacyjno-planistycznych. Specyfika tego pierwszego wiąże się z własnością wód, którą w prawie cze-

46 Vyhlaška č. 178/2012 Sb., kterou se stanovi seznam vyznamnych vodnich toků a způsob provaděni činnosti souvisejicich se spravou vodnich toků.

47 Zakon č. 305/2000 Sb. o povodich. 
skim pryncypialnie zanegowano, o czym już była mowa. Mamy $\mathrm{w}$ związku z tym w polskiej ustawie rozbudowane przepisy określające sposób wykonywania praw właścicielskich w odniesieniu do wód publicznych, które stanowią własność Skarbu Państwa (art. 11). Do podmiotów, które te uprawnienia realizują, należy: minister właściwy do spraw gospodarki morskiej (właściwość związana z wodami morza terytorialnego, morskimi wodami wewnętrznymi oraz wodami Zatoki Gdańskiej), Prezes Krajowego Zarządu Gospodarki Wodnej (najbardziej rozbudowana kategoria wód, w tym wody w śródlądowych drogach wodnych, wodach granicznych, ciekach naturalnych, w potokach górskich i ich źródłach), dyrektor parku narodowego (właściwy w stosunku do wód znajdujących się w graniach parku, z pewnymi wyjątkami) oraz marszałek województwa (realizujący zadanie zlecone z zakresu administracji rządowej), właściwy w stosunku do wód istotnych dla regulacji stosunków wodnych na potrzeby rolnictwa, służących polepszeniu zdolności produkcyjnej gleby i ułatwieniu jej uprawy oraz w stosunku do pozostałych wód. W drodze porozumienia wykonywanie uprawnień właścicielskich może zostać przekazane także nadleśniczemu (art. 11 ust. 1a). Inaczej zatem niż w Czechach, gdzie oddzielono administrowanie od wykonywania funkcji władczych przez właściwe organy administracji publicznej, w Polsce obie sfery zadań i kompetencji zostały organizacyjnie połączone.

W zasadzie nie ma w Polsce wód płynących, które należałyby do podmiotów samorządowych, niemniej ustawowa definicja własności wód takiej możliwości nie wyklucza. Przyjmuje się zatem, że ustawa jest koncepcyjnie otwarta na przeniesienie własności niektórych wód płynących na te podmioty. W odniesieniu do wód stojących oraz wód w rowach uprawnienia z nimi związane, ale też obowiązki, spoczywają na ich właścicielu, określanym na podstawie tytułu własności nieruchomości, na której wody te występują. Uprawnienia właścicielskie są jednakże mocno ograniczone poprzez konstrukcję korzystania zwykłego. Takie korzystanie z wód prywatnych, które wykracza poza ramy korzystania zwykłego, jest korzystaniem szczególnym, a więc realizowanym na takich samych zasadach, jak korzystanie szczególne z wód Skarbu Państwa. 
Administrowanie zasobami wodnymi z wykorzystaniem uprawnień reglamentacyjno-planistycznych uwzględnia podział państwa na obszary dorzeczy i regiony wodne. Inaczej niż w Czechach podziału tego dokonano bezpośrednio w ustawie Prawo wodne (art. 3).

\section{ADMINISTRACJA PAŃSTWOWA W GOSPODARCE WODNEJ}

Ostatni rozdział monografii został poświęcony państwowej administracji wodnej (statni sprava ve vodnim hospodařstvi). Zanim przejdziemy do prezentacji stanowiska autorów omawianej monografii, kilka uwag poświęcimy administracji państwowej w Republice Czeskiej. Jeśli chodzi o organy państwowej administracji centralnej (ustředni organy statni spravy), to nadal obowiązuje pochodząca jeszcze z okresu federacji ustawa Czeskiej Rady Narodowej o powoływaniu ministerstw i innych centralnych organów administracji państwoweje ${ }^{48}$ zwana ustawą kompetencyjną, kilkadziesiąt razy nowelizowana. W aktualnym stanie prawnym na administrację centralną składają się $^{49}$ ministerstwa w liczbie czternastu oraz urzędy centralne w liczbie jedenastu. Członkami rządu (vlady) są jedynie ministrowie, urzędami centralnymi kierują osoby, które nie wchodzą w skład rządu. Takimi urzędami centralnymi są m.in. Czeski Urząd Górniczy, Państwowy Urząd Bezpieczeństwa Jądrowego, Urząd Regulacji Energetyki.

Spośród ministerstw cztery mają znaczenie w postępowaniu z wodami:

- Ministerstwo Rolnictwa (Ministerstvo zemédélstvi), które wykonuje kompetencje centralnego urzędu wodnoprawnego, jeżeli ustawa wodna nie stanowi inaczej (§ 108 ust. 1 ustawy wodnej),

48 Zakon ČNR č. 2/1969 Sb., o zrrizeni ministerstev a jinych ustřednich organů statni spravy Česke republiky.

49 P. Průcha, Spravni pravo. Obecna čast, Brno-Plzeň 2012, s. 171-172. 
- Ministerstwo Środowiska (Ministerstvo životniho prostředi), którego kompetencje w sprawach wodnych wyznacza kilkanaście punktów w § 108 ust. 3 ustawy wodnej,

- Ministerstwo Komunikacji i Łączności (Ministerstvo dopravy a spojů) wykonujące kompetencje centralnego urzędu wodnoprawnego w sprawach wykorzystywania wód powierzchniowych do żeglugi (§ 108 ust. 4 ustawy wodnej),

- Ministerstwo Obrony (Ministerstvo obrany) wykonujące kompetencje centralnego urzędu wodnoprawnego w sprawach, w których administrację terytorialną sprawują wojskowe urzędy garnizonowe (§ 108 ust. 4 ustawy wodnej): Boletice, Brdy, Březina, Hradiště, Libava.

Organizacja administracji terytorialnej jest dość skomplikowana. Punktem wyjścia była nadal obowiązująca ustawa z 1960 r. o terytorialnym podziale państwa ${ }^{50}$. Ustawa wprowadziła podział państwa na siedem krajów $(k r a j e)^{51}$, przypisując do nich odpowiednie powiaty (okresy), te z kolei podzielono na gminy (obce) i garnizony wojskowe (vojenske ujezdy). Odrębną jednostkę stanowi stolica Praga podzielona na dziesięć dzielnic (obvody). Te siedem krajów to: Środkowoczeski z siedzibą w Pradze (12 powiatów), Południowoczeski z siedzibą w Czeskich Budziejowicach (8 powiatów), Zachodnioczeski z siedzibą w Pilznie (10 powiatów), Północnoczeski z siedzibą w Usti nad Łabą (10 powiatów), Wschodnioczeski z siedzibą w Hradec Kralove (11 powiatów), Południowomorawski z siedzibą w Brnie (14 powiatów), Północnomorawski z siedzibą w Ostrawie (11 powiatów). Kilkakrotnie nowelizowana Vyhlaška Ministerstwa Spraw Wewnętrznych z 2002 r. ${ }^{52}$ przyporządkowała gminy i garnizony wojskowe do poszczególnych powiatów. Podkreślić

50 Zakon č. 36/1960 Sb., o uzemnim členěni statu.

51 Czeskiego wyrazu kraj nie przekładamy, mimo że w opracowaniach polskich pojawiają się przekłady przez „okręg” bądź „region”, nie są one jednak udane już choćby dlatego, że w ramach kraju wyodrębniane są niekiedy regiony.

52 Vyhlaška č. 564/2002 Sb., o stanoveni uzemi okresů Česke republiky a uzemi obvodů hlavniho města Prahy. 
należy, że powiaty istnieją nadal, ale jako jednostki podziału terytorialnego, a nie jako urzędy, ponieważ urzędy powiatowe jako organy władzy państwowej zakończyły działalność z dniem 31 grudnia $2002 \mathrm{r}$.

Ówczesne kraje były pomyślane jako okręgi terytorialne, w których władza państwowa należała do rad narodowych krajów (krajske narodni vybory). Sytuacja zmieniła się po „aksamitnej rewolucji" 1989 roku. Nastąpił wtedy pierwszy etap reformy administracji terytorialnej. W podstawowym czeskim podręczniku prawa administracyjnego znajdujemy informacje, że już wiosną 1990 r. przeważył w nowych politycznych siłach pogląd, że reforma administracji terenowej nie zostanie przeprowadzona na bazie rad narodowych, lecz na innych zasadach:

- zniesienia całego systemu rad narodowych,

- przywrócenia samorządu na poziomie gmin i miast,

- utworzenia nowych monokratycznych organów administracji państwowej - urzędów powiatowych z mianowanymi naczelnikami,

- zniesienia rad narodowych na szczeblu krajów bez zastąpienia ich nowymi, przy czym ich kompetencje miały być rozdzielone między urzędy powiatowe i urzędy resortowe administracji państwowej,

- utworzenia w perspektywie wyższych jednostek samorządowych, przy czym początkowo brano pod uwagę samorząd powiatowy, dopiero potem przeważył pogląd, że to ma być samorząd ziemski lub regionalny ${ }^{53}$.

Dotychczasowy system rad narodowych został zastąpiony na nowo koncypowaną organizacją tzw. ogólnej administracji terytorialnej (všeobecna uzemni sprava), która na szczeblu podstawowym wprowadziła już w 1990 r. gminy jako jednostki samorządu terytorialnego, na szczeblu wyższym usytuowała urzędy powiatowe jako organy administracji państwowej o kompetencji ogólnej. Szczególne miejsce zajmowała stolica

53 D. Hendrych, Zaklady organizace veřejne spravy $w \check{C} R$, [w:] D. Hendrych a kolektiv, Spravni pravo. Obecna čast, Praha 2006, s. 136. 
Praga, która jako jednostka samorządowa miała własne przepisy rangi ustawowej ${ }^{54}$.

Konstytucja Republiki Czeskiej została uchwalona 16 grudnia 1992 r. i weszła w życie 1 stycznia 1993 r. Konstytucja zapowiedziała powołanie wyższych jednostek samorządu terytorialnego (vyšši uzemni samospravne celky), którymi miały być ziemie lub kraje (země nebo kraje) powołane przez odrębną ustawę konstytucyjną. Na taką regulację trzeba było czekać kilka lat, gdyż dopiero w 1997 r. została wydana ustawa konstytucyjna nowelizująca Konstytucję i wprowadzająca te wyższe jednostki samorządu terytorialnego ${ }^{55}$. Ustawa ta weszła w życie z dniem 1 stycznia 2000 r. Na jej podstawie powstało 14 wyższych jednostek samorządu terytorialnego:

1. Stolica Praga

2. Kraj Środkowoczeski z siedzibą w Pradze

3. Kraj Budziejowicki, aktualna nazwa - Południowoczeski z siedzibą w Czeskich Budziejowicach

4. Kraj Pilzneński z siedzibą w Pilznie

5. Kraj Karlovarski z siedzibą w Karlovych Varach

6. Kraj Ustecki z siedzibą w Usti nad Łabą

7. Kraj Liberecki z siedzibą w Libercu

8. Kraj Kralovehradecky z siedzibą w Hradec Kralove

9. Kraj Pardubicki z siedzibą w Pardubicach

10. Kraj Jihlavski, aktualna nazwa - Wysoczyzna z siedzibą w Jihlavie

11. Kraj Brneński, aktualna nazwa - Południowomorawski, z siedzibą w Brnie

12. Kraj Ołomuński z siedzibą w Ołomuńcu

13. Kraj Ostrawski, aktualna nazwa - Morawskośląski, z siedzibą w Ostrawie

14. Kraj Zliński z siedzibą z Zlinie.

54 P. Průcha, Spravni pravo, op.cit., s. 190.

55 Ustavni zakon č. 347/1997 Sb., o vytvořeni vyššich uzemnich samospravnych celků a o změně ustavniho zakona Česke narodni rady č. 1/1993 Sb., Ustava Česke republiky. 
W 2000 r. zostały wydane podstawowe, nadal obowiązujące ustawy samorządowe: o gminach ${ }^{56}$, o krajach $^{57}$, o stolicy Pradze $^{58}$. Ten drugi etap reformy terytorialnej administracji państwowej zamyka zakończenie działalności urzędów powiatowych z dniem 31 grudnia 2002 r. i przekazanie ich zadań po części gminom, po części krajom.

Od 1 stycznia 2003 r. terytorialna administracja państwowa o kompetencji ogólnej to wyłącznie dwuszczeblowa administracja samorządowa złożona z gmin i krajów, przy czym zarówno gminy, jak i kraje wykonują kompetencje z jednej strony samodzielne (samostatna puisobnost), z drugiej strony tzw. kompetencje przekazane (přenesena piosobnost), tj. kompetencje administracji państwowej przekazane (przeniesione, delegowane) z powiatów na gminy i kraje. Podstawę normatywną ku temu daje art. 105 Konstytucji, według którego wykonywanie administracji państwowej można powierzyć organom samorządowym tylko wtedy, gdy tak stanowi ustawa.

Konsekwencją tego założenia jest podział gmin na trzy kategorie (właśnie kategorie, a nie szczeble, ponieważ nie ma stosunku podrzędności i nadrzędności między tymi kategoriami). Według § 61 ust. 1 ustawy o gminach te kompetencje przekazane wykonują:

1. Gminy, których organy wykonują administrację państwową (kompetencje przekazane) tylko w podstawowym zakresie i tylko $\mathrm{w}$ obwodzie administracyjnym, który pokrywa się z obszarem gminy (kategoria I).

2. Gminy, których urzędowi gminnemu została powierzona ustawą kompetencja pověreneho obecniho uřadu, który wykonuje administrację państwową w szerszym zakresie niż gminy kategorii I i w większym obwodzie administracyjnym niż obszar jednej gminy (kategoria II).

3. Gminy o rozszerzonej kompetencji (obce s rozšiřenou pissobnosti), oznaczane także jako małe powiaty (,male

56 Zakon č. 128/2000 Sb., o obcich (obecni zřizeni).

57 Zakon č. 129/2000 Sb., o krajich (krajske zřizeni).

58 Zakon č. 131/2000 Sb., o hlavnim městě Praze. 
okresy"), których urząd gminny wykonuje jeszcze inne kompetencje przekazane w większym obwodzie administracyjnym niż gmina z kompetencjami powierzonymi (kategoria III) ${ }^{59}$.

Wykaz gmin z urzędem gminnym o kompetencjach powierzonych oraz gmin z rozszerzoną kompetencją znajduje się w załącznikach do specjalnej ustawy z 2002 r. $^{60}$

Mechanizm funkcjonowania gmin tych trzech kategorii przedstawia Petr Průcha w swoim podręczniku ${ }^{61}$. I tak:

Gminy „III”, których w Republice Czeskiej jest 205, są jednocześnie gminami „II”, których jest 388, i jednocześnie są także gminami „I”, których jest 6246. Oznacza to, że każda gmina „III” poza agendą właściwą dla niej w odpowiednim obwodzie administracyjnym, wykonuje, aczkolwiek z reguły w innym (naturalnie mniejszym) obwodzie agendę gminy „II” i jednocześnie dla swojego własnego obwodu wykonuje jeszcze agendę gminy „I”. Tak samo gmina „II”, która nie jest jednocześnie gminą „III” wykonuje obok agendy gminy „II” we właściwym obwodzie administracyjnym także agendę gminy „I" we własnym obwodzie administracyjnym. Dopiero do gmin „I” należy wykonywanie tylko „podstawowej” agendy kompetencji przekazanej, ale mogą się różnić tym, że niektóre należą do obwodu gminy II, która jest jednocześnie gminą „III”, podczas gdy inne gminy należą do obwodu gminy „II”, która nie jest gminą „III”, a kompetencje gminy „III” w stosunku do obywateli i obszaru takiej gminy wykonuje inna gmina z pozycją gminy „III”.

Ten nieco przydługi, ale jak sądzimy interesujący dla Czytelnika polskiego wstęp, był potrzebny, aby dobrze zrozumieć koncepcję administracji wodnej w prawie czeskim. Przepis § 104 ustawy wodnej w ust. 1 stanowi, że administrację państwową według tej ustawy wykonują urzędy wodnoprawne oraz Czeska

59 D. Hendrych, Zaklady organizace ..., op.cit., s. 129-130.

60 Zakon č. 314/2002 Sb,., o stanoveni obci z pověřenym obecnim uřadem a stanoveni obci s rozšiřenou působnosti.

61 P. Průcha, Spravni pravo, op. cit. s. 211-212. 
Inspekcja Środowiska ${ }^{62}$, po czym w ust. 2 precyzuje, że urzędami wodnoprawnymi (vodopravni urady) są:

a) urzędy gminne,

b) urzędy garnizonowe na obszarach garnizonów wojskowych,

c) urzędy gminne gmin o rozszerzonej kompetencji,

d) urzędy krajów,

e) ministerstwa jako centralny urząd wodnoprawny.

To wyliczenie nie ma wpływu na organy ochrony przeciwpowodziowej, o których mowa w \$77-81 ustawy wodnej (chodzi o komisje przeciwpowodziowe powoływane w odpowiednich urzędach).

Zwraca uwagę użycie przez ustawodawcę terminu „urząd” (uřad), a nie „organ”, jak było w okresie socjalistycznym. Zresztą już Konstytucja Republiki Czeskiej powróciła do znanego w okresie międzywojennym terminu „urząd”. Jak wyjaśniają przedstawiciele doktryny, pojęcie urzędu może mieć w języku czeskim trojakie znaczenie:

- ściśle określony przez ustawę krąg spraw przydzielonych jakiejś jednostce organizacyjnej lub bezpośrednio organowi jako ich kompetencja, którą wykonują zawsze osoby fizyczne jako monokratyczne lub kolegialne organy odpowiedniego podmiotu administracji publicznej (pojęcie funkcjonalne),

- ogólne oznaczenie jednostki organizacyjnej, której została przyznana pewna rzeczowa i miejscowa kompetencja (pojęcie instytucjonalne), które jest zbieżne z poprzednio stosowanym pojęciem organu,

- zespół osób przydanych organowi do pomocy przy wykonywaniu jego urzędu (funkcji), tworzący jednostkę organizacyjną (pojęcie tworu pomocniczego) bez pra-

${ }^{62}$ Czeska Inspekcja Środowiska jest podstawowym organem kontrolnym działającym na podstawie ustawy z 19 czerwca 1991 r. - Zakon Česke narodni rady č. 282/1991 Sb., o Česke inspekci životniho prostředi a jeji působnosti v ochraně lesa. Kompetencje Inspekcji w sprawach „wodnych” zakreśla § 112 ustawy wodnej. 
wa wydawania abstrakcyjnych lub konkretnych aktów prawnych.

Współczesne prawo administracyjne pojmuje „urząd” w jego drugim, instytucjonalnym znaczeniu. Tylko te osoby fizyczne, którym powierzono kierowanie urzędem administracyjnym, działają prawnie w zakresie jego kompetencji w imieniu podmiotu administracji publicznej ${ }^{63}$.

Na czele urzędu gminnego stoi starosta, który w większych miastach zwany jest primatorem, na czele urzędu kraju - hejtman.

Przepis §126a ustawy wodnej potwierdza, że kompetencje przyznane tą ustawą urzędowi kraju, urzędowi gminnemu gminy z rozszerzoną kompetencją, urzędowi gminnemu o kompetencjach powierzonych lub urzędowi gminnemu, a także ich komisjom przeciwpowodziowym są wykonywane jako kompetencje przekazane, czyli kompetencje administracji państwowej.

W wykazie urzędów wodnoprawnych z $\S 104$ ust. 2 nie ma urzędów gminnych z kompetencjami powierzonymi (pověrene obecni uřady), czyli gmin „II”. Autorzy omawianej monografii wskazują, że wykreślenie ich $\mathrm{z}$ wykazu nastąpiło 1 sierpnia 2010 r. Przedtem miały one „przybliżyć” administrację publiczną obywatelom tym, że wydawały pozwolenia na pobór $\mathrm{i}$ inne postępowanie $\mathrm{z}$ wodami oraz na budowle wodne (przede wszystkim studnie), z wyjątkiem odprowadzania ścieków do wód powierzchniowych i podziemnych. Doświadczenia okazały się negatywne, świadczące o konieczności co najmniej minimalnego poziomu jakości wykonywania administracji państwowej przez urzędy wodnoprawne, który mogą gwarantować dopiero urzędy gminne gmin o rozszerzonej kompetencji.

Urzędom gminnym (gmin „I”) ustawa wodna w § 105 ust. 1 przyznaje tylko kompetencje wskazane z $\S 6$ ust. 4, tzn. urząd gminy może powszechne korzystanie z wód bez rekompensaty uregulować, ograniczyć lub zakazać, jeżeli tego wymaga interes publiczny, ale nawet tego nie może uczyć na wodach granicznych.

63 D. Hendrych, Pravni zaklady organizace, [w:] D. Hendrych a kolektiv, Spravni pravo. Obecna čast, Praha 2006, s. 103-104. 
Urzędom garnizonowym ustawa wodna w §105 ust. 2 przyznaje na obszarach garnizonów wojskowych zadania urzędów gmin z rozszerzoną kompetencją, ale z wyjątkiem pobierania opłat według rozdziału $\mathrm{X}$ ustawy wodnej i wymierzenia administracyjnych kar pieniężnych (pokuty) według rozdziału XII tej ustawy.

Podstawowym zagadnieniem organizacyjnym jest podział zadań między gminy o rozszerzonej kompetencji a kraje. Ustawa wodna w $\S 106$ ust. 1 wyznacza kompetencje urzędu gminy jako kompetencje pozostałościowe (zbytkove), co oznacza, że urząd gminy o rozszerzonej kompetencji jest właściwy zawsze, jeżeli ustawa wodna nie powierza określonej kompetencji innym organom. Chodzi tu przede wszystkim o kompetencje urzędów krajów, które wylicza $\S 107$ ust. 1 pod literami od a) do y). Ustawodawca czeski posłużył się dwiema odrębnymi metodami:

- albo określona kompetencja należy do wyłącznej właściwości urzędu kraju; tytułem przykładów pozwalanie na odprowadzanie ścieków do wód powierzchniowych ze źródła o wielkości 10000 i więcej mieszkańców przeliczeniowych ( $\$ 107$ ust. 1 lit. k) czy też pozwalanie na piętrzenie i akumulację wód powierzchniowych w zbiornikach o objętości ponad $1000000 \mathrm{~m}^{3}$ lub wysokości piętrzenia ponad $10 \mathrm{~m}$ (§ 107 ust. 1 lit. n),

- albo określona kompetencja należy do urzędu kraju, jeżeli ten ją sobie zastrzeże; tytułem przykładu pozwalanie na postępowanie $\mathrm{z}$ wodami $\mathrm{w}$ celu wykorzystania ich potencjału energetycznego na znaczących ciekach wodnych w przypadkach, gdy sobie to zastrzeże (§ 107 ust. 1 lit. j).

Najistotniejsze z punktu widzenia ochrony interesów wodnych postanowienie zawiera $\S 104$ ust. 9 ustawy wodnej, zgodnie z którym w postępowaniach prowadzonych według ustawy o ochronie przyrody i krajobrazu ${ }^{64}$, ustawy górniczej ${ }^{65}$, ustawy o działalności górniczej, materiałach wybuchowych i admi-

65 Zakon č. 44/1988 Sb., o ochraně a využiti nerostneho bohatstvi. 
nistracji górniczeje6 i dalej przy postępowaniu według ustawy budowlanej ${ }^{67}$ przy lokalizacji, pozwalaniu, wykorzystywaniu i usuwaniu budowli można wydać decyzję lub dokonać innej czynności prawnej tylko na podstawie wiążącego stanowiska urzędu wodnoprawnego, jeżeli miałyby być dotknięte interesy chronione ustawa wodną. Do tego przepisu nawiązuje § 107 ust. 2 ustawy wodnej, według którego urzędy krajów są dotkniętymi organami (dotčeny organy) w rozumieniu § 104 ust. 9 i wydają wiążące stanowiska w sprawach należących do ich kompetencji.

\section{POLSKA ADMINISTRACJA GOSPODARKI WODNEJ}

Ogólnie przyjąć można, że administrację wodną tworzą te wszystkie jednostki, które wykonują ustawowe zadania państwa z zakresu gospodarki wodnej. W ich skład wchodzą przede wszystkim organy administracji publicznej (rządowej i samorządowej), ale także inne podmioty o niejednolitym statusie (np. instytuty badawcze realizujące zadania państwowej służby hydrologiczno-meteorologicznej, państwowej służby hydrogeologicznej oraz państwowej służby do spraw bezpieczeństwa budowli piętrzących, jak również spółki wodne, przy czym te drugie trudno już zaliczyć do kategorii podmiotów „państwowych").

Stosownie do roli ustrojowej, jaką w systemie gospodarki wodnej spełnia ustawa - Prawo wodne, uwagę należy skierować przede wszystkim na organy administracji wodnej w niej przewidziane. W myśl art. 4 ust. 1 organami właściwymi w sprawach gospodarowania wodami są:

a) minister właściwy do spraw gospodarki wodnej - jako organ naczelny,

66 Zakon č. 61/1988 Sb., o hornicke činnosti, vybušinach a o statni baňske spravě.

67 Zakon č. 183/2006 Sb., o uzemnim planovani a stavebnim řadu (stavebni zakon). 
b) Prezes Krajowego Zarządu Gospodarki Wodnej - jako centralny organ administracji rządowej, nadzorowany przez minister właściwy do spraw gospodarki wodnej,

c) dyrektor regionalnego zarządu gospodarki wodnej jako organ administracji rządowej niezespolonej, podlegający Prezesowi Krajowego Zarządu Gospodarki Wodnej

d) wojewoda - jako organ administracji rządowej zespolonej,

e) organy jednostek samorządu terytorialnego.

W powyższym wyliczeniu pominięto niektóre inne organy, które także wykonują uprawnienia władcze na podstawie przepisów ustawy. Chodzi o organy administracji morskiej (ustalanie linii brzegu dla morskich wód wewnętrznych - art. 15 ust. 2 pkt 1 oraz określanie reżimu prawnego na obszarze pasa technicznego - art. 83 ust. 3), a także organy realizujące funkcje kontrolne na podstawie przepisów rozdziału 7 (organy Inspekcji Sanitarnej oraz Inspekcji Ochrony Środowiska). Nie uwzględnia on także aparatu administracyjnego samorządu wojewódzkiego (niemającego cech organów administracji publicznej), który spełnia ważne funkcje w zakresie utrzymania wód i urządzeń wodnych (chodzi o wojewódzkie zarządy melioracji i urządzeń wodnych realizujące zadania w imieniu marszałka województwa). Tylko nieliczne zadania i kompetencje przyznane zostały przepisami ustawy organom gminy. Dotyczą one spraw lokalnych, a konkretnie stosunków wodnych na gruntach sąsiednich oraz niektórych aspektów korzystania powszechnego z wód. Wspomnieć w końcu należy o organach administracji leśnej, żeglugowej, geologicznej i górniczej, utworzonych na podstawie przepisów odrębnych ustaw działowych.

\section{PODSUMOWANIE}

Analizowana tu w aspekcie porównawczym monograficzna rozprawa czeskich autorów dowodzi aktualności i uniwersalności problematyki prawnej gospodarowania wodą. Ten dział 
prawa administracyjnego ma w Czechach i w Polsce długą tradycję legislacyjną, opartą na tych samych wzorcach. Poświęcona mu refleksja prawna korzysta z tych samych narzędzi prawnych, pozostających w kręgu kultury prawnej kojarzonej z państwami niemieckojęzycznymi. Obok wspólnych korzeni znacząca dla współczesnego prawa wodnego w obu krajach jest także jego perspektywa rozwojowa, wynikająca $\mathrm{z}$ europejskich tendencji prawnoustrojowych. Znajdują one swój wyraz w dążeniu do ujednolicenia rozwiązań prawnych w tym zakresie. Za potrzebą taką przemawia przede wszystkim egzystencjalna rola zasobów wodnych, których ochrona musi uwzględniać zmiany środowiskowe zachodzące w skali globalnej.

Upodabnianie się prawa wodnego w skali europejskiej nie wyklucza wszakże zachowania przez krajowe porządki prawnej pewnej specyfiki, związanej przede wszystkim z kwestiami ustrojowymi. Z tego powodu najpoważniejsze różnice w rozwiązaniach czeskich i polskich ujawniają się w kwestiach organizacji aparatu administracyjnego. Wynikają one z dość oczywistego faktu, że w każdym kraju kształt administracji jest wypadkową wielu czynników, takich np. jak wielkość obszaru państwa, doświadczenia historyczne, pozycja kadry urzędniczej i innych. Różnice znajdujemy także w podejściu do doktrynalnej koncepcji własności wód, choć dla praktyki administracyjnej nie ma to większego znaczenia.

Z kolei podobieństwa dotyczą przede wszystkim prawa materialnego, w tym zakresu regulacji i zasad zarządzania systemowego, a także doboru instrumentów prawnych. W tej części widoczny jest wpływ prawodawstwa europejskiego, a przede wszystkim rozwiązań przyjętych do dyrektywy 2000/60, WE Parlamentu Europejskiego i Rady z dnia 23 października 2000 r. ustanawiającej ramy wspólnotowego działania w dziedzinie polityki wodnej. 


\section{BIBLIOGRAFIA}

Damohorsky M. a kolektiv, Pravo životniho prostředi, Praha 2010.

Gniewek E., Prawo rzeczowe, Warszawa 2010.

Hendrych D., Zaklady organizace veřejne spravy $w \check{C} R$, [w:] D. Hendrych a kolektiv, Spravni pravo. Obecna čast, Praha 2006.

Horaček Z., Kral M., Strnad Z., Vytejčkova V., Vodni zakon. II vydani s podrobnym komentařem po velke novele stavebniho zakona $k$ 1.1.2013, Praha 2013.

Kałużny M., Prawo wodne. Komentarz, Warszawa 2012.

Karpus K., Planowanie $w$ gospodarowaniu wodami, [w:] Wybrane problemy prawa wodnego, pod red. B. Rakoczego, Warszawa 2013.

Klima K. a kolektiv, Komentař k Ustavě a Listině. 1. dil, Plzeń 2009.

Mikulski Z., Osiemdziesiąt lat polskiego prawa wodnego 1922-2002, „Gospodarka Wodna” Nr 11/2003.

Praškova H., Zaklady odpovědnosti za spravni delikty, Praha 2013.

Průcha P., Spravni pravo. Obecna čast, Brno-Plzeň 2012.

Rakoczy B. (red.), Wybrane problemy prawa wodnego, Warszawa 2013.

Rakoczy B. (red.), Z. Bukowski, K. Szuma, Prawo wodne. Komentarz, Warszawa 2013.

Rotko J., Linia rozwojowa polskiego prawa wodnego, [w:] Prawo i polityka w ochronie środowiska. Studia z okazji 40-lecia pracy naukowej Jerzego Sommera, Wrocław 2006.

Rotko J., Ramowa dyrektywa wodna - analiza prawna, Poznań 2013.

Sladeček V., Obecne spravni pravo, Praha 2013.

Kontakt e-mail:

rotkojerzy@poczta.onet.pl 